\title{
Sustainable Local Weaving Ecosystem for Cultural Tourism (Study of Toba Sibandang Traditional Weaving in Muara District, North Tapanuli Regency, North Sumatra)
}

\author{
Soni Sadono ${ }^{1}$, Catur Nugroho ${ }^{2}$ \\ ${ }^{1}$ Telkom University, Bandung, Indonesia, sonisadono66@gmail.com, 082186628004. Lecturer at Creative \\ Industry of Telkom University Bandung. Doctor of Cultural Studies from Padjajaran University Bandung. Since \\ 2012 to 2017, Sadono active as Student Manager Telkom University. \\ ${ }^{2}$ Telkom University, Bandung, Indonesia, mas pires@yahoo.com, 085228191449. \\ Since joining the Telkom University in 2014, Nugroho has been involved with studies related Media and \\ Cultural Studies, and also the studies of Gender and Democracy. Before joining University, Nugroho worked at a \\ education company as a branch manager. Since 2013 Nugroho worked as a lecturer of FISIP Unsera, Banten, \\ Indonesia. Catur also active in Digital Literacy National Movement Siberkreasi since 2017 as Coordinator of
} Research Team.

\begin{abstract}
This paper is based on the traditional weaving as one of the handicrafts of the people in the area is believed to be able to take a role in it. The scope of tourism is chosen because tourism is an industrial sector that is quick yielding and opens up new opportunities for the tourism industry in the Lake Toba region, which has only focused on nature tourism. The approach used in this study is a Cultural Resources Management (CRM) with the mindset that traditional weaving and inheritance aspects are aimed at empowering the economy in order to provide sustainable community benefits. The analysis was carried out qualitatively with an ethnographic study approach. This study seeks to see and reveal whether traditional weaving-based cultural tourism has economic value, because it contains the concept of preservation and cultural inheritance, economics, education, and based on community empowerment. This research also see the weaving potential mapped in its distribution correlated with tourist objects that have been seeded by the North Tapanuli Regional Government resulting in clusters that can be developed into tourism packages oriented to market demand, without ignoring the empowerment of local communities. Although weaving is believed to be able to increase the tourism market in Sibandang Island, there are still a number of obstacles, namely in the fields of promotion, strengthening of weaving crafts, and the creation of tourism conscious communities. The root of the problem of the three obstacles is the lack of public awareness of the Ulos Sibandang weaving as one of the cultural artifacts that has been passed down for hundreds of years.
\end{abstract}

Keywords: cultural tourism, ecosystems, traditional weaving, Cultural Resources Management DOI: $10.7176 / \mathrm{ADS} / 77-09$

Publication date:October $31^{\text {st }} 2019$

\section{INTRODUCTION}

Sibandang Island is located in the north of Muara District, consisting of three villages with an area of approximately 850 hectares, surrounded by Lake Toba, directly adjacent to Samosir Island, and Humbang Hasundutan District (Humbahas). The natural beauty of Sibandang Island with its cool climate and natural beauty is very potential for tourism development. Tourism potential on Sibandang Island in addition to its natural beauty also has several potentials in the cultural sector, especially the Ulos woven handicrafts that have existed since hundreds years ago. The potential of the original craft Sibandang, if combined with good natural tourism, can be an attractive tour package for national and international tourists.

The uniqueness of Sibandang traditional weaving is the manufacturing process which is still manual and passed down from generation to generation. Sibandang traditional weaving crafts become a very interesting cultural attraction. Weaving that can be found in Papande village, Sibandang Island, Muara Subdistrict, North Tapanuli Regency has high value potential, both in terms of material and its intellectual value. Collectively, tradition and the lives of people on Sibandang Island condition sustainability and traditional weaving inheritance. However, a number of issues that are feared to affect the sustainability of these ulos weaving handicrafts are also found, among others, that Sibandang traditional weaving does not provide economic benefits (profit) for the craftsmen community. In fact, its own creation requires working capital that is not small and quite a long time. In addition, Sibandang ulos weaving is one of the fields that can create employment for local residents. One form of utilization of Sibandang traditional weaving resources that is in line with its potential and condition is to place it 
as part of the tourism industry by promoting local community empowerment. The choice of this form of utilization is based on the fact that the trend in the global tourism industry in the 21 st century is cultural tourism (Butler, 1997. Fletcher, 1997), where weaving is believed to be able to take an important role in it. Equally important, the source of reference in this study is the central government's policy of placing the Lake Toba region as one of the priorities of the national tourism area development. In addition, with this research, it is also expected that there will be an increase in regional potential through the tourism sector and the export scale handicraft industry by utilizing the cultural ecosystem in Papande village, Sibandang.

Since Sibandang traditional weaving as cultural heritage, the approach used in this study is a Cultural Resources Management (CRM) approach with the framework of thinking that traditional weaving and inheritance aspects are aimed at economic empowerment so that it can provide benefits to the community on an ongoing basis. This research seeks to see and reveal how cultural cultural tourism is based on traditional weaving crafts with economic value. Traditional weaves contains the concept of preservation and cultural inheritance, economy, education, and based on community empowerment (Atmosudiro, et all, 2003).

Furthermore, we also see the weaving potential mapped in its distribution correlated with tourist objects that have been seeded by the North Tapanuli Regional Government resulting in clusters that can be developed into tourism packages oriented to market demand, without ignoring the empowerment of local communities. The method used in this study is a qualitative research method with an ethnographic study approach, where research is focused on understanding unique and specific phenomena or events, in this case traditional weaving crafts on the island of Sibandang. The perpetrators of ulos weaving craft are understood as individuals who inherited culture from generation to generation and will inherit it to the next generation. Also they as individuals who have social, economic and cultural interests will be seen how their daily lives as workers of ulos weaving.

There are a number of obstacles in the development of traditional weaving culture ecosystems in Papande village, Sibandang, namely the lack of promotion of natural and cultural tourism of Sibandang island as one of the main tourist destinations in the Lake Toba region, and lack of reinforcement of weaving as one of the local cultural heritage that must be preserved. in addition, there is also a lack of public awareness of Sibandang traditional weaving as one of the cultural artifacts that has been passed down for hundreds of years. Based on the background and identification of the research problems above, the formulation which is the focus of the study in this study is how the Sibandang traditional weaving cultural ecosystem can contribute to the tourism culture based on local culture, and what are the things needed so that traditional weavers in Sibandang can taking part in the tourism industry in the Lake Toba region.

\section{Research Method}

The method used in this study is a qualitative method, with a new ethnographic study approach. In this study, the researcher intends to see, understand, describe and describe in depth about a phenomenon that is the focus of the problem, namely the existence of traditional Sibandang woven crafts as cultural heritage and cultural tourism assets. Given that weaving is cultural heritage which is an unrenewable sources, the approach used in this study is a cultural resource management approach. The object of this research is the process and strategy of inheritance of traditional weaving handicraft culture in Sibandang Island, Muara District, North Tapanuli Regency, North Sumatra. The heritage of traditional weaving culture is the main object of research to be associated with the potential of natural tourism on the island of Sibandang. As a cultural tourism asset, traditional weaving cultural attractions will be observed directly by using social and cultural approaches, to be able to understand the existence and philosophical meaning of traditional weaving Sibandang in the eyes of the community. The process of making traditional weaving as cultural heritage will be seen, documented and analyzed in depth by involving cultural actors as primary informants as well as research subjects.

\section{RESULT AND DISCUSSION}

The informants in this study were people who were considered to understand the development of traditional weaving in the Lake Toba area, especially those that developed on Sibandang Island, precisely in Papande Village, Muara District, North Tapanuli Regency. some informants who could be found by the research team and had the capacity to explain the traditional weaving culture ecosystem in Papande village in the following table. 
Table 1. Informants of the research

\begin{tabular}{|c|c|c|}
\hline Name & Occupation & Evidence \\
\hline Erison Siregar & $\begin{array}{l}\text { Traditional } \\
\text { Weaver, } \\
\text { Papande } \\
\text { Elementary } \\
\text { School } \\
\text { tetacher }\end{array}$ & $\begin{array}{l}\text { One of the weavers in Papande village whose } \\
\text { weaving works have been widely used by people } \\
\text { in the Toba area and even arrived in Jakarta. In } \\
\text { addition, Erison Siregar is an elementary school } \\
\text { teacher at Papande State Elementary School. }\end{array}$ \\
\hline Kape Siregar & $\begin{array}{l}\text { Community } \\
\text { leaders in } \\
\text { Papande } \\
\text { village and } \\
\text { elementary } \\
\text { school } \\
\text { senior } \\
\text { teacher in } \\
\text { Sibandang }\end{array}$ & $\begin{array}{l}\text { One of the community leaders in the village of } \\
\text { Papande, Sibandang Island who understands } \\
\text { enough about the development of woven } \\
\text { craftsmen and at the same time the Papande } \\
\text { Elementary School teacher. }\end{array}$ \\
\hline Emy Pakpahan & $\begin{array}{l}\text { Young } \\
\text { woman } \\
\text { Weaver }\end{array}$ & $\begin{array}{l}\text { A student at one of the private university in } \\
\text { North Tapanuli. Weaving skills are learned from } \\
\text { elementary school age. Currently active in } \\
\text { weaving in the midst of busy lectures. }\end{array}$ \\
\hline Paloma Pakpahan & $\begin{array}{l}\text { Young } \\
\text { woman } \\
\text { weaver }\end{array}$ & $\begin{array}{l}\text { young weavers who inherit the ability to weave } \\
\text { from their parents. } 15 \text { years old and still in high } \\
\text { school in Muara sub-district. }\end{array}$ \\
\hline Duta Siregar & $\begin{array}{l}\text { Young } \\
\text { weaver }\end{array}$ & $\begin{array}{l}\text { The fourth generation of weaver families started } \\
\text { learning to weave since elementary school age. } \\
14 \text { years old, and still studying at N Muara } \\
\text { Middle School. }\end{array}$ \\
\hline $\begin{array}{ll}\text { Amang } & \text { Monang } \\
\text { Naipospos } & \end{array}$ & $\begin{array}{l}\text { Batak Toba } \\
\text { Observer }\end{array}$ & $\begin{array}{l}\text { One of the cultural leaders in the Lake Toba area } \\
\text { who was involved with weavers and understood } \\
\text { the history of traditional weaving. }\end{array}$ \\
\hline
\end{tabular}

Sibandang Island is one of the small islands found in Lake Toba and has fertile land and is known as the Sibandang mango producer. There are about 30 weavers in Papande village who are still actively weaving with traditional looms. They worked on weaving orders from the tauke who were also providers of yarn which was the main raw material of woven fabrics. Weavers in Sibandang do weaving according to the motif or design that has been ordered by the tauke or order from the Regional Arts and Crafts Council (Dekrasnasda) North Tapanuli Regency. The majority of weavers in Papande are women who are also housewives, and are a buffer for the family economy from weaving.

Weaving crafts in the village of Papande, Sibandang island has existed since the days of their ancestors inhabiting the island, and inherited from generation to generation to the next generation. But the existence of Sibandang weaving and weavers now face many problems related to inheritance of weaving skills to the younger generation in Papande. As stated by Kape Siregar as one of the community leaders in Papande who took part in the development of weaving in Sibandang, that the young generation in Papande are currently very few who want to learn to weave, because according to them weaving is a very difficult thing to learn. And again, young people here see parents who work as weavers of their lives not prosperous.

The culture of weaving on Sibadang Island is an asset that must be protected and preserved. Various parties must work together to conserve this weaving culture. Cultural preservation carried out from generation to generation must be maintained so that the weaving of Sibandang is not extinct. The inheritance of weaving art from our ancestors to our children and grandchildren can now be stopped if there is no process of converging and revitalizing weaving. The inheritance of weaving cultural artifacts can be hampered if you see the interest of the younger generation who are not interested in learning to weave. With extraordinary natural resources and beauty, Sibandang Island has the potential to become a tourism area based on nature and culture.

In an interview with Erison, he said that weaving activities were studied and carried out from generation to generation. As the only male weaver in Papande, Erison is the third generation of weaver families. Erison who 
has learned to weave since elementary school, by looking at what her mother and sister have done. As he stated that he saw his mother and sister working like this (weaving), so when they were not home, Erison did it alone. most weavers learn weaving from their own families. The science of weaving is not taught from school education, only from the family. The way of learning is not structured or neat as a teacher teaches his students. However, it is self-taught by seeing and paying attention to their parents or siblings when doing weaving activities.

Table 2. The Naming of Toba Weaving Process

\begin{tabular}{|c|c|}
\hline Name & Explanation \\
\hline $\begin{array}{l}\text { Thread coloring } \\
\text { (manubar and } \\
\text { mansop) }\end{array}$ & $\begin{array}{l}\text { Woven fabrics made of yarn spun from cotton. The yarn is } \\
\text { originally white, and to get the red color is called "manubar" and } \\
\text { to get the color black is called "mansop". The coloring material of } \\
\text { ulos weaving was made from leaf material, such as the avocado } \\
\text { leaves which are fermented to become the desired color. However, } \\
\text { nowadays it is very rare to see the coloring of ulos weaving using } \\
\text { natural dyes, because most of the threads used have been colored } \\
\text { with chemical coloring. }\end{array}$ \\
\hline $\begin{array}{l}\text { Make a design } \\
\text { (Manggatip) }\end{array}$ & $\begin{array}{l}\text { Manggatip comes from the word "gatip", which means an image } \\
\text { or design that is on ulos woven fabric. The graphical circuit found } \\
\text { in ulos was created when the thread was strung to a standard size. } \\
\text { This string is called a "lump". Gatip or ulos weaving designs are } \\
\text { made before the coloring is done. The desired thread remains } \\
\text { white, tied with a binding material consisting of fiber or } \\
\text { lemongrass leaves. This process is now a process that many } \\
\text { weavers have missed, because their own expertise and skills are } \\
\text { needed to be able to create ulos weaving. So the majority of } \\
\text { weavers now hand over gatip or designs to people who are experts } \\
\text { in weaving design, and not many people are left in the Toba area. }\end{array}$ \\
\hline $\begin{array}{l}\text { Brightening the yarns } \\
\text { (Mangunggas) }\end{array}$ & $\begin{array}{l}\text { Mangunggas is the process of enlightening the yarns. In general, } \\
\text { yarns that have finished being smeared or shoveled, the color is } \\
\text { arnsrather dull. This yarns is paved to give a more brilliant } \\
\text { impression. People who do this work are called "pangunggas" } \\
\text { with "pangunggasan" equipment. The thread is smeared with } \\
\text { melted rice then rubbed with a round brush from the fibers. The } \\
\text { melted rice is usually called "indahan ni bonang". The yarn that } \\
\text { has been spun is somewhat springy and decomposes after being } \\
\text { dried in the hot sun. }\end{array}$ \\
\hline $\begin{array}{l}\text { Stringing Yarn } \\
\text { (Mangani) }\end{array}$ & $\begin{array}{l}\text { The yarn that has been finished being peeded then enters the } \\
\text { finishing process called "mangani". But to make it easier to } \\
\text { mangani, the thread was previously "hugged" or rolled in the form } \\
\text { of a ball. The tool needed is "anian" which consists of a piece of } \\
\text { wood on which a short stick is attached to the size of the desired } \\
\text { ulos. In this process, craftsmanship determines the beauty of ulos } \\
\text { according to the size and calculation of the number of threads } \\
\text { according to the color composition. }\end{array}$ \\
\hline Weave (Martonun) & $\begin{array}{l}\text { Tonun (weaving) is the process of forming threads that have been } \\
\text { "bred" into a piece of ulos cloth. In the language of the Toba } \\
\text { Batak people it is commonly called "partonun". }\end{array}$ \\
\hline $\begin{array}{l}\text { Decorate weaving } \\
\text { (Manirat) }\end{array}$ & $\begin{array}{l}\text { The final process makes the whole ulos "manirat". The person } \\
\text { who does this work is called "panirat". Sirat is a signpost } \\
\text { decoration on both ends of the ulos fabric. Sirat is usually formed } \\
\text { with a gorga motif (typical Toba wood carvings). }\end{array}$ \\
\hline
\end{tabular}

The activity of cultural inheritance of weaving in Papande village is still carried out by Erison at her parents' house. There were 3 (three) nephews of Erison who were interested in learning to weave, the first was a nephew who was 18 years old and still studying at one of the private colleges in Siborong-borong named Emy Pakpahan. 
Emy has learned to weave from elementary school by seeing the martonun activities her mother and uncle do at home. Guided by his mother and uncle, Emy is now able to weave using fine threads, which have a higher level of difficulty than weaving with coarse threads. This fine thread produces a softer woven fabric and a more expensive price than woven fabric with coarse yarn. Emy said that she had learned to weave from elementary school age, starting from the process of $\mathrm{m}$ Weaving to being able to skillfully weave fine woven fabrics.

Another generation of weavers is a 15-year-old girl named Paloma Pakpahan. Boru Paloma has been learning to weave since elementary school by seeing and observing the weaving activities carried out by her mother and uncle everyday. Paloma is now able to carry out mangani and martonun activities, which are usually done after returning from school at Muara Public High School, North Tapanuli Regency. The successor to the weaving skills is Duta, aged 14, who is still in junior high school in Muara sub-district. At the moment the new Ambassadors can carry out the process, which is to string threads that will be woven into rolls so that they are easy to process partonun. On the sidelines of his activities helping work in the fields after going home from school, Duta still wants to learn to weave from his uncle, cousin and aunt. The initial lesson he did was mangani, which aims to introduce people who want to learn to weave with woven threads, so that their hands and fingers become accustomed to holding and playing threads. Duta even though a man had the enthusiasm to learn to weave because he was motivated by his uncle, Erison, who could weave from the initial process of coloring threads, made designs, and weaved ulos woven fabrics.

The challenge in inheriting weaving is indeed felt by Erison as a person who has a concern for the sustainability of Toba weaving. Erison teaches the process of weaving to the neighbors in Papande village, even to some people outside Sibandang island who are the target for him to preserve the weaving culture. However, not many local people have a strong intention to preserve it, especially young people. There are only a few young people in Papande who want to learn to weave, because they sometimes feel embarrassed to learn and even do the weaving activities themselves. In addition, the absence of a special place to study the weaving process has also become a separate obstacle in the inheritance of weaving culture.

Erison as a male weaver figure on Sibadang Island wants to own and build a studio for him to share the culture of weaving. For him studio is a media that can facilitate him to foster the community in learning weaving. But until the time this research was conducted in July and August 2018, weaving studios could not have been established as Erison had intended as a place to study weaving for children and adolescents in Papande village. In addition to the lack of concern of the local community for this weaving activity, Erison was also faced with the difficulty of obtaining land that can be established by a weaving studio. Even to borrow land that is behind the primary school where Erison teaches, until the research was carried out it had not received permission from the North Tapanuli District Education Office. Even though weaving studios, inheritance of weaving to the younger generation will be easier.

Weaving culture is not a cheap thing but a wealth asset, not seen from wealth (money) but because weaving is a cultural ecosystem that must be preserved. Because in addition to being one of the cultural heritages, weaving can also be a driver of the community's economy. Especially since the introduction of weaving using fine threads, weaving products have become more economically valuable and can help the economy of the community. In addition, with the existence of a studio, weaving activities are expected to become one of the cultural attractions that can attract the attention of local and foreign tourists. It can also be a workshop of the works of weavers in the village of Papande to be better known to the public at large.

Sibadang Weaving began to be organized and preserved with the support of the local government. The direction of the National Secretariat helps them to improve the economic well-being of weavers while at the same time adding to the distinctive value of Sibadang itself. With Ulos weaving, weavers can expand their network. Not only from Indonesia but also abroad. Even the handicrafts of Erison Siregar have been used by Indonesian President Joko Widodo when visiting Toba Lake. A sense of pride because the work was not only felt by Erison but also felt by the area where Erison was located, namely Papande village, Sibadang island. The exhibition and festival are often followed by Erison as a representative of traditional Sibadang weavers. He once used traditional weaving in several ceremonial events in the government and distributed his woven fabric to several people for free to introduce the Sibandang weave cloth. A pride of weaving that originates from Sibadang can rise to the Indonesian scene. Exports can reach Korea to America. A sense of pride from the community in introducing cultural values through a work that can be enjoyed by many people. Works that contain very high value and quality because each fabric is made manually, even the dyes used are natural dyes. The motifs that have become characteristic of Sibadang weaving are from ancestors. All come from the work of the creativity of the ulos weavers themselves.

Weaving activities in Papande village, Muara Subdistrict which have been going on for a long time are actually very feasible to be appointed as cultural tourism destinations. With the geographical conditions of Sibandang Island which are very beautiful and attractive, tourists will be able to enjoy the beauty of nature and at the same 
time enjoy cultural tourism in the form of traditional weaving ecosystems. But the potential of nature and culture on Sibandang Island is still not optimally utilized by the community and the local government. Even some of the traditional Toba Batak houses in Sibandang are also neglected and have been severely damaged, even though the traditional houses also have very high cultural and historical values. The combination of traditional weaving cultural attractions with traditional Toba Batak houses will be one of the economic value tourism destinations if packaged and marketed well. The existence of weavers in Papande village is one of the largest weaver communities in the Lake Toba area, because in other places weavers are usually spread in several villages or villages.

The fostering and preservation of weaving culture even though it is still in the stage of permanent pioneering continues to be carried out by local residents, especially weavers. Sibadang traditional weavers, as explained in the previous sub-chapter, that the tradition of weaving in Papande village, Sibandang island, originates from ancestors inherited from generation to generation. Traditional Sibandang weaving besides as a cultural artifact, as well as and is a tradition. The purpose of these weavers is to preserve culture, they also seek livelihoods and economic improvement from weaving. The result is that their woven products are still just in accordance with orders that come from "tauke" (agents) or from Dekranasda, North Tapanuli Regency. With these conditions, the income of the weavers in Papande village still cannot contribute maximally to the family and regional economy. The weaving activities and processes carried out by weavers in Papande have not been "sold" to tourists who come to the Lake Toba area. In addition, there is no concept of a tourist village, making the potential and natural resources and cultural resources available on Sibandang Island not of maximum economic value. If it is utilized and cultivated in earnest, the potential of nature and culture on Sibandang island can be a source of income for people in the region.

Collaboration between weavers and designers to make a fashion model based on local cultural wisdom has not been well established. To make one ulos cloth, sometimes between weavers make an agreement in the distribution of each suit for a shirt which later the product or order will be deposited to the government for resale. Amang Monang Naipospos In his interview said that "the weaver can be three people, one weave the side, one weave his body, one weave his head ... who do they collaborate eventually ... the output of the ulos ...". This can benefit and improve the quality of human resources in Sibandang itself. There is an increase in their welfare. The weaving culture is expected not to stop at just one generation point. If other regions already have the nickname weaving. So at Sibadang, they also want to raise and give the characteristic weaving of their original area, Ulos.

\section{Conclusion}

From this research, we can conclude a number of things as follows:

1. Inheritance and conservation of cultural ecosystems Traditional weaving on Sibandang Island, Papande Village, Muara District, North Tapanuli Regency has not been able to run well. This happens because the traditional weaving culture inheritance system has not been able to run from generation to generation systematically and sustainably. Only a few young people want to learn to weave and inherit traditional weaving culture in Sibandang. The government's role has not been seen optimally to help weavers in Sibandang develop and be sustainable and make a positive contribution to the development of cultural tourism.

2. Sibandang traditional weaving has not been managed properly, so it has not been able to contribute to the culture-based tourism industry in North Tapanuli Regency (Lake Toba Region). The traditional weaving production process which is merely to fulfill the request from the buyer or tauke is not used as a tourist attraction that can attract the attention of national and international tourists, to complement the natural tourism of Toba Lake areas.

3. Better and more sustainable guidance is needed from various parties who have attention to the sustainability of traditional weaving in Sibandang, so that they can make a positive contribution to the surrounding community. In addition, local government intervention is needed to facilitate the realization of traditional weaving culture studios in Sibandang so that cultural preservation of this ancestral heritage can be maintained.

\section{Acknowledgement}

The District Government of North Tapanuli

Toba Odyssey

Society of Papande Village, Muara sub-district, North Tapanuli district, North Sumatera. 
Erison Siregar Big Family

\section{References}

Atmosudiro, Sumijati, D.S. Nugrahani, Chr. Wisma Nugraha Rich., Sektiadi, (2003). Cultural Tourism Model Based On Weaving In Lombok. Gadjah Mada University, Departement of Anthropology.

Buttler, Richar W., 1997. "The Destination Life Cycle: Implication for Heritage Site Management and Attractivity”. Dalam Wiendu Nuryanti (ed.), 1997. Tourism and Heritage Management. Yogyakarta: Gadjah Mada University Press, hlm 44-53.

Cavallaro, Dani (2001) Critical and Cultural Theory. London: The Athlone Press.

Fletcher, John, 1997. "Heritage Tourism: Enhancing the Net Benefits of Tourism”. dlm Wiendu Nuryanti (ed.), Tourism and Heritage Management. Yogyakarta: Gadjah Mada University Press, hlm 134-46.

Indrayanti, Sukma. (2001) Media and Modern Society. Yogyakarta: Kencana Mega.

Atmosudiro, Sumijati, D.S. Nugrahani, Chr. Wisma Nugraha Rich., Sektiadi, (2003). Cultural Tourism Model Based On Weaving In Lombok. Gadjah Mada University, Departement of Anthropology.

McGrew, Anthony. Stuart Hall, \& David Held (eds.), (1992) Modernity and Its Future: Understanding Modern Societies. New York: Polity Press. 